\title{
Refractory Neoplasm
}

National Cancer Institute

\section{Source}

National Cancer Institute. Refractory Neoplasm. NCI Thesaurus. Code C7628.

A neoplasm that does not respond to treatment. 